\title{
(In)Complete acquisition of Turkish among Turkish German bilinguals in Germany and Turkey: an analysis of complex embeddings in narratives
}

Article

Accepted Version

Treffers-Daller, J., Ozsoy, A. S. and van Hout, R. (2007) (In)Complete acquisition of Turkish among Turkish German bilinguals in Germany and Turkey: an analysis of complex embeddings in narratives. International Journal of Bilingual Education and Bilingualism, 10 (3). pp. 248-276. ISSN 13670050 doi: https://doi.org/10.2167/beb443.0 Available at https://centaur.reading.ac.uk/29880/

It is advisable to refer to the publisher's version if you intend to cite from the work. See Guidance on citing.

To link to this article DOI: http://dx.doi.org/10.2167/beb443.0

Publisher: Routledge

Publisher statement: This is an Author's Original Manuscript of an article whose final and definitive form, the Version of Record, has been published in the International Journal of Bilingual Education and Bilingualism [version of record 22 Dec 2008] [copyright Taylor \& Francis], available online at: http://www.tandfonline.com/doi/abs/10.2167/beb443.0 
copyright holders. Terms and conditions for use of this material are defined in the End User Agreement.

\section{www.reading.ac.uk/centaur}

\section{CentAUR}

Central Archive at the University of Reading

Reading's research outputs online 
Version 26 January 2007

Jeanine Treffers-Daller (University of the West of England, Bristol), A.Sumru Özsoy (Boğaziçi University) and Roeland van Hout (Radboud University, Nijmegen)

(In)complete acquisition of Turkish among Turkish-German bilinguals in Germany and Turkey: an analysis of complex embeddings in narratives

keywords: bilingualism, incomplete acquisition, Turkish, German, bilingual education

address for correspondence:

Jeanine Treffers-Daller

University of the West of England, Bristol

Faculty of Humanities, Languages and Social Sciences

School of Languages, Linguistics and Area Studies

Frenchay Campus

Coldharbour lane

Bristol BS16 1QY

email: jeanine.treffers-daller@uwe.ac.uk

fax: 00-44-117-3282820 


\section{Abstract}

Although most researchers recognise that the language repertoire of bilinguals can vary, few studies have tried to address variation in bilingual competence in any detail. This study aims to take a first step towards further understanding of the way in which bilingual competencies can vary at the level of syntax by comparing the use of syntactic embeddings among three different groups of Turkish-German bilinguals.

The approach of the present article is new in that different groups of bilinguals are compared with each other, and not only with monolingual speakers, as is common in most studies in the field. The analysis focuses on differences in the use of different types of embeddings in Turkish, which are generally considered to be one of the more complex aspects of Turkish grammar. The study shows that young Turkish-German bilingual adults who were born and raised in Germany use fewer, and less complex embeddings than Turkish-German bilingual returnees who had lived in Turkey for eight years at the time of recording. The present study provides new insights in the nature of bilingual competence, as well as a new perspective on syntactic change in immigrant Turkish as spoken in Europe.

Keywords: bilingualism, bilingual education, German, incomplete acquisition, syntax, Turkish

\section{Introduction ${ }^{\mathrm{i}}$}

The main aim of this study is to clarify the linguistic implications of what Grosjean (1997: 165) has called the complementarity principle: "Bilinguals usually acquire and use their languages for different purposes, in different domains of life, with different people. Different aspects of life require different languages." Therefore the language repertoire of bilinguals reflects their particular need for and use of each language. As Grosjean (2004: 36) puts it, the complementarity principle explains why bilingual children and bilingual adults are not 
two monolinguals in one person. Unfortunately many studies in which bilinguals are used as subjects fail to give detailed information about the subjects' language repertoire (Grosjean 2004). The present study is new in that it gives an in-depth description of the use of complex embeddings by three different groups of bilinguals, and investigates whether there are quantitative or qualitative differences in the use the groups make of these structures in narratives.

The second aim of the study is to come to a better understanding of the issue of ultimate attainment in bilingual acquisition. While many studies focus on bilingual acquisition in childhood, little is known about the levels of attainment achieved by bilinguals in adulthood. In view of the lack of evidence about ultimate attainment, Birdsong (2004: 33) calls for a "finer-grained investigation of the limits of bilingualism". Several authors point to the fact that there is increasing evidence that even bilinguals who have been brought up using two languages do not always converge on the grammars of native speakers (Polinsky 2004; Montrul 2002). To our knowledge, no studies have been done on the ultimate attainment or incomplete acquisition of Turkish among adult bilinguals who were born in Germany and have lived all their life in this country.

As Polinsky (2004) points out, little is known about the structural properties of incomplete acquisition. The question we are trying to answer in this paper is to what extent Turkish-German bilinguals in Germany should be considered to be incomplete learners' of Turkish, with respect to their use of complex embeddings. We could argue that they should be so considered if the study reveals that the bilinguals in Germany do not master all these structures and/or use them in ways that are markedly different from the way they are used by Turkish-German bilinguals who live in Turkey and monolingual Turkish informants. Studying this group of bilinguals is particularly relevant for the discussion about incomplete acquisition, because we have information about the language competence of different groups of Turkish-German bilinguals: one group who live in Germany, a group of returnees who returned to Turkey a few months prior to the data collection and a group who had been back for eight years at the moment of data collection. An analysis of the language of the returnee groups can tell us whether a change in circumstances (i.e. moving to a Turkish-dominant environment) can trigger the acquisition of additional aspects of Turkish grammar. 
We expect the sociolinguistic background of the speakers (their linguistic biography) to be clearly linked to the bilinguals' use of the relevant structures: those who are in everyday contact with Turkish as spoken in Turkey (the returnees who had lived in Turkey for eight years and the monolingual control group) are expected to use more, and more complex embeddings than those who have lived so far in environments where German is the dominant language of society (Turkish-German bilinguals in Germany and bilinguals who have just returned to Turkey). The originality of the paper resides in our view in the fact that it demonstrates the diversity in syntactic proficiency found among different groups of Turkish-German bilinguals ${ }^{\mathrm{ii}}$. It thus provides evidence for the linguistic consequences of the changes in language choice patterns among returnees, whose use of Turkish increases dramatically after their arrival in Turkey (Daller 1996, 1999), although they continue to speak German with other returnees and at school or at university (see section 3 for more details). ${ }^{\text {iii }}$ As we have shown in other papers (Daller 1999, Treffers-Daller \& Van Hout 1999, Daller, Van Hout \& Treffers-Daller 2003), the groups of Turkish-German bilinguals differ significantly from each other on various measures of vocabulary richness, but so far no analysis of the informants' syntactic proficiency has been conducted. The current paper aims to fill this gap.

The insights obtained in this paper are important for a number of reasons. First of all, an in-depth understanding of the Turkish language competence of young people is relevant for schools, teachers and educational policy makers in Western Europe in general and Germany in particular; Turks form the largest minority group in Germany's borders: $25.6 \%$ of all foreigners are Turks. ${ }^{\text {iv }}$ Germany is home to the EU's largest Turkish population at 1.88 million, and these figures do not include the 575,000 Turks who have obtained German nationality since 1972 (Özcan 2004). As the Programme for International Student Assessment, better known as the PISA study ${ }^{\mathrm{v}}$, has shown, the school results obtained by students from immigrant backgrounds fall behind those who are not from immigrant backgrounds in literacy, maths and science. The situation of Turkish students forms a particular cause for concern. A comparison between the students with Turkish backgrounds and those from Poland or the former Soviet Union shows that the results of the former are well below those of the latter group (Stanat 2003). In the second place Turkish used by immigrants can inform us about the development of 
these varieties of Turkish and the ways in which these differ from Turkish as spoken in Turkey, and this point is developed further in section 2, followed by a more detailed presentation of the focus of the current study (section 3). After that, we give an overview of complementation in Turkish (section 4). Subsequently we introduce the different groups under investigation and we go into the methodology followed to collect our data in section 5. The quantitative and qualitative results are presented and analysed in section 6. In the final section we discuss our results in the light of the research questions, and we present some questions for future research. 
From the work of many researchers working on bilingualism it is known that Turkish as spoken by Turkish people who grew up in Europe differs from Turkish as spoken in Turkey. Because of concerns for the difficult position of Turkish children in mainstream education in Western Europe, a considerable number of studies focus on Turkish spoken by pre-school children and primary school children of the second or even the third generation (Verhoeven \& Boeschoten 1986; Rehbein 1987; Boeschoten 1990; Pfaff 1991 \& 1994; Schaufeli 1991, Preibusch 1992; Karasu 1995), and on comparisons between the Turkish of these children and those who grow up in Turkey. Less is known about the Turkish proficiency of Turkish adolescents and young adults who grow up in Europe (Boeschoten 1992; Menz 1994, Sar1 1995; Auer \& Dirim 2000). An important aspect of the work in this area concerns the way in which different contact languages influence varieties of Turkish spoken in Europe. Slobin was probably the first to point out that contact between Turkic languages and Indo-European languages often results in Turkic speakers replacing the participle constructions used in the formation of relative clauses by more analytical forms, while keeping the Turkic inflectional morphology intact. According to Slobin (1977: 194), "this has happened in Azerbaijani under the influence of Persian, to Karaite Turkish in the Crimea under Russian influence, to Gagauz Turkish under Romanian influence and in several other cases." After having pointed out that relative clause constructions are acquired much later in L1 acquisition of Turkish, than in L1 acquisition of an Indo-European language such as Serbo-Croatian, Slobin (1977: 194) proposes the following general principle of language contact:

\footnotetext{
"Forms which are late to be acquired by children are presumably also relatively difficult for adults to process, and should be especially vulnerable to change."
}

Slobin points out that the Turkic relative clause constructions as well as verb complement constructions are potentially vulnerable in situations of language contact. It is therefore possible that Turkish as spoken in Germany (and elsewhere in Europe) is undergoing change in that certain forms of complex embeddings (in particular the verbal complements and the participial forms used to form relative clause constructions) are replaced with more analytical forms. We hope to contribute to this discussion on language change in 
immigrant varieties of Turkish by analysing the syntactic structures used by young Turkish people in Germany, and this may lead to a new perspective on the characteristics of Turkish as spoken in Europe. According to Johanson (1999: 251), however, it is highly dubious whether any of the young immigrant varieties in Northwest Europe develop into new varieties of Turkish, although in many studies the development of mixed codes is discussed (Backus 1996; Issa 2005; Türker 2000).

\section{The focus of the current study}

The focus of this paper is on differences in the production of complex embeddings (see below) between three groups of Turkish-German bilinguals (aged 16-20) and a monolingual Turkish control group (aged 20). More specifically, we are interested in the differences between a group of bilinguals who live in Germany, a group of returnees who are recorded upon return to Turkey, and a group of returnees who had been back for eight years upon recording. We have included a monolingual control group in this study as we are interested in the question whether returnees who have had extensive exposure to Turkish as spoken in Turkey are (still) different from Turkish monolinguals. We are aware of the fact that comparing monolinguals and bilinguals is problematic (Grosjean 1992) and generally disadvantageous for the bilinguals. We need to keep this in mind when comparing the returnees to monolinguals and we need to realise that we are only studying one half, that is the Turkish half, of their language repertoire.

The inclusion of a group of recent returnees allows us to establish to what extent Turkish bilinguals use embeddings from the moment they start living in Turkey. Many returnees point out that they had language problems upon arrival in Turkey, especially at school. One informant from the returnee group told us that "it took her about a year after return to be able to speak Turkish reasonably well”, ${ }^{\text {vi }}$, but it remains unclear in what areas the speaker claims to have incomplete knowledge. Although it is well-known that bilinguals sometimes underestimate their proficiency in either language, it is not unlikely that there is a growth in Turkish proficiency during the first year after return. At the moment of their arrival in Turkey most returnees enter a Turkish-speaking school environment for the first time in their life and it is likely that this presents a challenge to their language repertoire. As Grosjean (1998: 132) puts it: “(...) the language repertoire of bilinguals may change over time: as the environment changes and the needs for particular language skills also change, so will their 
competence in their language." The present study gives a first indication as to the changes that occur in bilinguals' language repertoires due to changes in the need for both languages.

We focus on subordination, because this has been observed to be a relatively complex part of Turkish grammar. Özsoy and Erguvanl1-Taylan (1989) showed subordination to be problematic for foreign language learners of Turkish. This is particularly the case for complement clauses in -mA and relative clauses, the so-called participial constructions in yAn and -DIK (see below for details of these constructions) ${ }^{\text {vii }}$. Slobin $(1977 ; 1986)$ shows that Turkish children who grow up monolingually do not master relative clauses until the age of $4 ; 8$, and several authors point to the fact that relative clauses are difficult for many Turkish children in Europe as well (Boeschoten 1990; Menz 1994). Fritsche (1982) makes a remark concerning the absence of complement clauses in Turkish as spoken in Germany by children and adolescents. Aksu-Koç (1994) shows that complement clauses are late to appear in L1 acquisition of Turkish: complements in -DIK do not appear until the age of 5 in the narratives (frog stories), and the complements in - mA are only found in narratives of a 9-year old and of adults.

In his summary of the literature on immigrant Turkish, after having pointed out that there are no systematic studies so far, Backus (2004: 715) mentions the existence of a tendency towards "the replacement of synthetic means of clause linkage and subordination (or at least their decreasing usage), especially of relative clauses, by simple juxtaposition", as described by Aarssen (1996), Bayraktaroğlu (1999) and Akinci and Jisa (2000). Verhoeven (1989; 1991; in Verhoeven 2004: 439) found clear evidence of stagnation in the use of clauselinking devices among immigrant Turkish children (age six to eight) in the Netherlands. In addition, the use of syntactic features to mark dependency and embeddedness appeared to pose major problems for Turkish children in the Netherlands: among the eight year olds less than half of the children used any of the devices available to mark dependence (Verhoeven 2004: 440). Verhoeven points to impoverished input as the likely cause of the stagnation in development of these structures and concludes that the "findings show the second generation of Turkish migrants living in the Netherlands not to attain native-like levels of proficiency" (p. 443).

Although the number of studies focusing on adolescents and young adults is very limited, the available evidence seems to indicate that the problems continue beyond the primary school age. El Aissati and Schaufeli (1999) show that Turkish immigrants of the second generation in the Netherlands (aged between 14 and 18) and a Turkish control group of the same age and with the same socio-economic background used fewer relative clauses in 
a production task, based on the frog stories (Mayer, 1969), although there was no difference on a task that measured perception of these structures. The authors conclude that "more subjects in the second generation group than in the control group tend not to use relative clause constructions" (El Aissati \& Schaufeli 1999: 373). The authors do not discuss other forms of embeddings, although they mention that postpositional constructions were not considered. The results are important because they may indicate that the Turkish immigrants of the second generation do not attain native-like competence in Turkish. Even students who are close to adulthood avoid using relative clauses, and one would expect these to be mastered at that age.

Yağmur (1997) and Yağmur, De Bot and Korzilius (1999) are the only authors who have studied the use of relativisation among adults. They focus on attrition of relativisation among two groups of first generation Turkish immigrants in Australia who had been in Australia for at least fifteen years at the moment of investigation: a group of immigrants with eleven years of schooling (mean age 54.4) and a group of immigrants with five years of schooling (mean age 50.5). The authors show that the immigrant groups do less well than control groups in Turkey on a relativisation production task, and that the better educated group obtain higher scores on this task than the lesser educated group. For the purpose of the current paper it is particularly relevant that the differences between the groups are related to differences in educational level, and to the fact that immigrants who received education through the medium of $\mathrm{L} 1$ have a better command of relativisation in Turkish. Yağmur (1997: 96) concludes that

"living in a second language environment causes erosion in first language skills, but education received in the first language plays a role in the maintenance of L1 skills: a relatively high L2 proficiency goes together with a relatively high L1 proficiency level."

Yağmur also demonstrates that educational level explains the differences in performance of two monolingual control groups that were asked to perform the same task. The monolingual reference group that was better educated obtained significantly higher scores on the relativisation task than the less well educated group. It is possible that the former use Turkish for a wider range of functions than the latter, which may result in the better educated group having more opportunities for using a wide range of syntactic 
constructions.

In summary, the available evidence seems to lend support to Slobin's (1977) thesis that Turkic relative clause constructions (and other forms of complex embeddings) are vulnerable in situations of language contact, and there appears to be some evidence that Turkish immigrants do not completely acquire complex embeddings. It remains difficult to draw firm conclusions as yet, because precise details of the constructions that were investigated are not always provided in the literature. A comprehensive study of the acquisition of complex embeddings has not been made so far, and the current paper aims to fill this gap.

\section{Complementation and relative clause formation in Turkish}

In this section we will outline how noun clauses, adverbial clauses and relative clauses are structured in Turkish, illustrating the different structures with examples from the recordings made in the three bilingual groups and the monolingual control group (see section 5). For each example we give the name of the group (Bielefeld, Bursa, Marmara or Üsküdar) and the identifier of the informant. In the examples the embedded clauses are presented in brackets, and the relevant suffixes are given in capital letters and bold typeface for ease of recognition ${ }^{\text {viii }}$.

\subsection{Noun clauses}

In Turkish complementation involves the use of a nominalisation strategy wherein the embedded verb is marked with one of the set of nominaliser suffixes. Kornfilt (1997) and Özsoy (1999) distinguish two types of noun clauses, those whose predicate is marked with a suffix called an Action Nominal marker (-mA), as in (1) and those marked by a Factive Nominal marker (-DIK), as in (2).

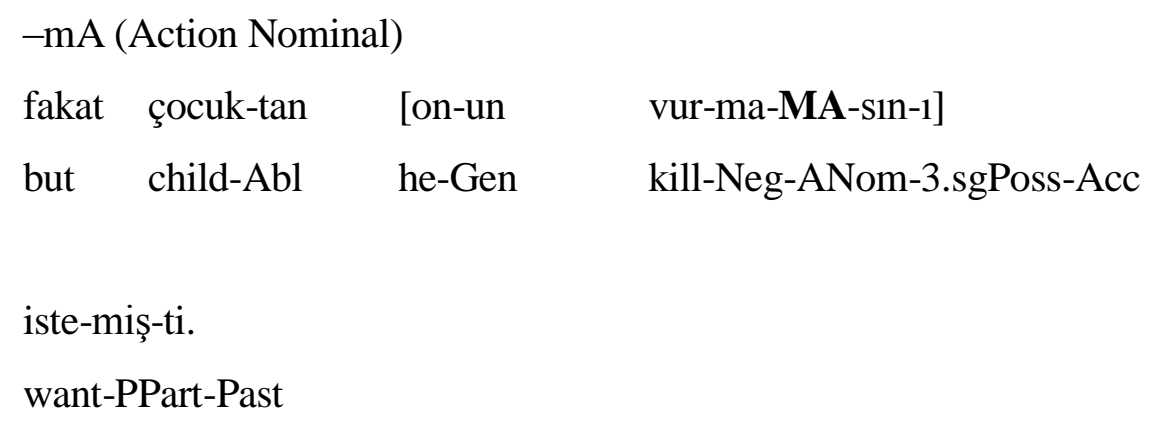


"But he (=the father) didn't want the child to kill it (=the bee)" (Bursa, Zeynep)

-DIK (Factive Nominal)

Çocuk heralde [top-a

Child no doubt ball-Dat

zanned-iyor

think-Prog-
vur-DUĞ-un-u ]

hit-FNom-3.sgPOSS-Acc

"The child no doubt thinks he hit the ball." (Bursa, Şengül)

The choice of Action versus Factive morphology is largely determined by semantics, and some verbs allow for either type of complement. The whole clause is marked with the case marker assigned by the verb governing the clausal complement which appears as the outermost layer of suffixes on the verbal complex of the complement clause (Özsoy, 1999). In both (1) and (2), for example, the clausal complements are marked by the accusative case.

In structurally determined cases, there is agreement between the subject of the embedded clause and the predicate. In those cases where they are definite, the overt subject NPs of non-control verbal complements, i.e. complement clauses whose subjects are overtly present in the structure and which are not co-referential with an NP in the matrix clause, are marked with the genitive suffix and agree in number and person with the predicate of the embedded clause. This is illustrated in (1), where the subject $o$ 'he' is marked with a genitive suffix $-u n^{i x}$, which establishes agreement in number and person with the predicate vur-ma-masin-l 'kill-Neg-ANom-3.sgPOSS-Acc'. The embedded verb vur-ma-ma-sin-l is marked with the possessive agreement marker $-\sin$. In (2) the subject of the main clause and the subordinate clause are identical, and there is no overt subject of the subordinate clause. Agreement is marked with the possessive $-u n$ on the embedded verb vur-duğ-un- $u$ 'hitFNom-3.sgPOSS-Acc'.

The complement with the Action Nominal has a variant, the infinitive -mAK, where the subject of the embedded clause is identical with the subject or object of the matrix clause. This is illustrated in (3) where çocuk '(the) child' is the subject of both the main clause and the complement clause, whereas in (1) the subject of the main clause is the father and the subject of the complement clause is the child. There is no possessive on the embedded verb because the verbs of these infinitival clauses are not marked for person or number agreement with the matrix subject. 


$$
\begin{aligned}
& -\mathrm{mAK} \\
& \text { Çocuk [öldür-MEK] ist-iyor } \\
& \text { child kill-Inf want-Prog } \\
& \text { "The child wants to kill (it)." (Bursa, Sevgi) }
\end{aligned}
$$

Within the -DIK/-AcAK forms a future/non-future distinction can be drawn. Factive nominals can be marked for future tense, in which case the -DIK suffix is replaced by the form -AcAK, as in (4). In clauses with Action Nominals, however, future tense cannot be expressed with this suffix. Agreement is marked on the embedded verb with a possessive suffix, as in the case of noun clauses in -DIK. Thus, in (4) the -in suffix is the possessive agreement marker in uç-acağ-1n-1 'fly-FNomFut-3.sg-Acc'. The genitive marking on the subject is not visible in (4), as the subject of the noun clause is not overtly expressed.

$$
\begin{array}{llll}
\text { (4) } & \text {-AcAK } & & \\
\text { hani } & \text { bu } & \text { saye-de } & \text { [uç-ACAĞ-1n-1] } \\
\text { Int } & \text { this } & \text { consequence-Loc } & \text { fly-FNomFut-3.sgPOSS-Acc }
\end{array}
$$

zanned-iyor

believe- Prog

"He (=the father) believes that he (= the bee) will fly away in this way." (Bursa, Aysel)

\subsection{Adverbial clauses}

Nominalisation is also a common process in the case of adverbial clauses (VP adjuncts). For our purposes, we have classified VP-adjuncts as (i) postpositional clauses and (ii) gerunds. The clausal complements of postpositional clauses involve nominalisation processes similar to those described for verbal complementation. The verb is marked with one of the nominalising suffixes and the appropriate agreement marker. The nature of the agreement marker is determined by the postpositional head (Özsoy 1999). Where the postpositional clauses differ from verbal complementation is, however, in the agreement pattern of the subjects in the non-control constructions. While the definite subjects of the verbal complements are always marked with the genitive, those of the postpositional clauses are marked with either the nominative, which also typically occurs on the subject of matrix 
clauses, or with the genitive suffix. In (5), for example babast 'his father' has nominative case.

\begin{tabular}{|c|c|c|c|}
\hline [baba-s1 & on-a & k1z-DIĞ-1 & \\
\hline father-3.sg & he-Dat & be.angry-FNom-3.sgPOSS & because \\
\hline \multicolumn{2}{|c|}{ oğlan ağla-ma-ya } & başl-1yor & \\
\hline cry- & Nom-Dat & start-Prog & \\
\hline
\end{tabular}

In (6) the postposition dolayl 'because' is preceded by a complement clause of which the subject kafa-sl-nın 'head-3.sgPoss-Gen' is assigned genitive case.

$$
\begin{array}{lll}
\begin{array}{l}
\text { Çocuk ağl-1yor } \\
\text { child cry-Prog }
\end{array} & \begin{array}{ll}
\text { [adam-1n } \\
\text { man-Gen }
\end{array} & \begin{array}{l}
\text { kafa-sın-1n } \\
\text { head-3.sg-Gen }
\end{array} \\
\text { şiş-TIĞ-in-den } & \text { dolay1] } \\
\text { swell.up-FNom-3.sgPOSS-Abl } & \text { because } \\
\text { "The child cries because the man's head has swollen up." (Marmara, Lütfü) }
\end{array}
$$

No case marking can be found on the complement clause klz-diğ- $\iota$ 'be.angry-FNom-3.sg' of the postposition için in (5) 'because' için does not assign any overt case. In (6) however the complement şiş-tiğ-in-den 'swell.up-FNom-3.sgPoss-Abl' of the postposition dolay1 'because' bears the ablative case marking selected by the postposition.

The other class of VP-adjuncts, i.e. gerunds, are formed by the assignment of one of a number of gerundive suffixes to the embedded verb. There are two types of gerunds: those whose verbs are marked for agreement, as in (7), and those whose verbs are not marked for agreement, as in (8). In both examples the gerundive suffixes are given in bold capital letters for ease of recognition. In (7) the adverbial clause is marked for agreement with the subject in the form of the third person singular agreement marker $i n$. In (8) there is no agreement on the embedded adverbial clause. 
(7) Adam-1n kafa-s1 man-Gen head-3.sg şiş-iyor,

[dışarı çık-tiğ-ın-DA]

swell.up-Prog outside leave-FNom-3.sgPOSS-Loc

"When he gets out (of the hole)." (Bursa, Nalan)

(8)

$\begin{array}{lllll}\text { [Çocuk } & \text { baba-sın-1 } & \text { sev-EREK] } & \text { ev-e } & \text { gid-iyor-lar } \\ \text { child } & \text { father-3.sgPOSS-Acc } & \text { love-Ger } & \text { house-Dat } & \text { go-Prog-3Pl }\end{array}$

"The child embracing his father they go home." (Bielefeld, Aysel)

The lexical subjects of those gerunds which license overt subjects are marked nominative, as can be seen in (9) where çocuk is the subject of the gerund, and it is marked nominative.

$\begin{array}{lll}\begin{array}{l}\text { En sonunda } \\ \text { most end-3.sg-Abl }\end{array} & \begin{array}{l}\text { tabii ki } \\ \text { of course }\end{array} & \begin{array}{l}\text { [çocuk sevgi-sin-i } \\ \text { child love-3.sgPOSS-Acc }\end{array} \\ \text { gösterdiğ-in-DEN] } & \text { barış-1yor-lar } \\ \text { show-FNom-3.sgPOSS-Abl } & \text { reconcile-Prog-Pl }\end{array}$

"Finally, of course they are reconciled since the child has shown his love (to him). (Marmara, Birgül)

\subsection{Relative clauses}

NP-adjuncts are participle clauses that are formed with the assignment of one of the set of participle suffixes to the embedded verb, the most common participle suffixes being -(y)An or -DIK/-(y)AcAK generally referred to as the 'subject participle (SubjP)' and 'object participle (ObjP)' participles respectively (cf. Underhill, 1972). The choice between these two suffixes is beyond the scope of this paper, but it is treated in some detail in Kornfilt (1997: 57 onwards). In the case of the -(y)An strategy, which is exemplified in (10), the embedded subject is deleted if it is semantically marked as definite. In the examples below the relative clauses are bracketed, and the participle suffixes are given in bold capital letters.

$$
\begin{aligned}
& -(\mathrm{y}) \mathrm{An} \\
& {\left[\begin{array}{l}
\text { ön-üm-de } \quad \text { dur-AN] } \\
\text { front-1.sg-Loc }
\end{array} \text { stay-SubjP } \quad\right. \text { picture-PL-Abl }} \\
& \text { "Of the pictures that are in front of me ..." (Bursa, Nalan) }
\end{aligned}
$$


The -DIK/-(y)AcAK strategy, which applies when the target of the relativization is a nonsubject constituent, involves the assignment of one of the participle suffixes as well as the nominal agreement marker to the embedded verb. Examples (11) and (12) illustrate the use of - DIK and -(y)AcAK as relativization strategies. Thus in (11) agreement is marked with the third person singular marker ' 1 ' on yap-TI $\breve{G}-l$ 'do-ObjP-3.sgPoss' and in (12) with 'i' on gid$\boldsymbol{E} \boldsymbol{C E} \breve{\boldsymbol{G}}-i$ 'go-Fut.ObjP-3.sgPoss'.

$$
\begin{aligned}
& \text {-DIK } \\
& \begin{array}{lll}
\text { [çocuğ-un } & \text { yap-TIĞ-1] } & \text { davranış-1 ... } \\
\text { child-Gen } & \text { do-ObjP-3.sgPOSS } & \text { behaviour-Acc }
\end{array} \\
& \text { "The action (that was) performed by the child ..." (Marmara, Gülay) }
\end{aligned}
$$

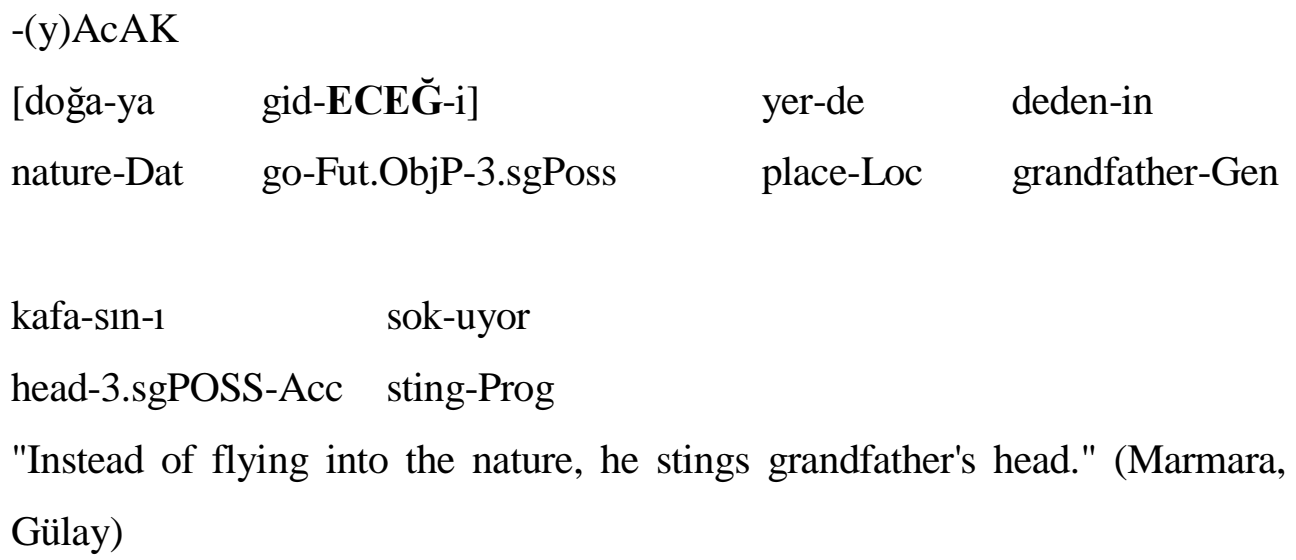

\subsection{Markedness of complementation and relativization strategies}

In the following sections we have somewhat simplified the subclassifications distinguished here and grouped them under six different labels. The verbal complements in -DIK and (y)ACAK are taken together and referred to as -DIK. The other two nominalisation strategies discussed above are labelled -mAk and -mA. The two categories of VP-adjuncts are referred to as PPs and gerunds. All NP-adjuncts are summarised in one category labelled -(y)AN.

Within the premises of a framework which takes the number of obligatory inflectional morphemes following the nominalisation suffix on a verb stem in the different categories of embedded clauses as well as the occurrence of an overt case marker (i.e. genitive) on the embedded subject as an indication of morphological markedness, Özsoy and Erguvanl1-Taylan (1989) propose ranking the embedded clauses in Turkish in terms of their markedness as follows: 
Least marked - gerunds (VP-adjuncts)

Less marked - participles (NP-adjuncts)

Marked - nominalisations

Most marked - postpositional clauses (VP-adjuncts)

In their analysis of the production of embedded clauses by foreign speakers at intermediate and advanced levels of competence, Özsoy and Erguvanl1-Taylan have observed that, at the outset of an eight week intensive language course, the lowest percentage of mistakes in embedding was found in the use of gerunds, i.e. adjunct clauses whose verbs are marked with a nominalisation suffix but not with the possessive marker. The percentage of mistakes made in the rest of the categories was in accordance with the predictions of the markedness theory, with only the relative percentages of nominalisations and postpositional clauses, nominalised clauses headed by a postposition, positing a contradiction to these predictions. The results of the intensive language instruction indicated complete mastery of the participle structures, while problems still persisted in the use of gerunds as well as other embedded structures. Özsoy and Erguvanl1-Taylan attribute this unpredicted result to the emphasis placed on the teaching of participles. Another finding in this study that seems to contradict the predictions of the markedness theory was that foreign speakers had fewer problems with postpositional clauses than with nominalisations, even though both categories exhibited more problems than gerunds, even at the end of the language program. Özsoy and Erguvanl1-Taylan propose that, in addition to the number of morphemes on the verb and the subject of the embedded clauses in Turkish, the function of the embedded clauses needs to be taken into consideration in predicting problem areas for foreign speakers.

\section{Methodology}

In this paper we compare four groups of informants, each of which will briefly be introduced here. An overview of the details is given in Table 1. More details about the social and educational background of the Bursa and the Bielefeld informants can be found in Daller (1999).

Table 1 about here - 
We study three bilingual groups and one monolingual control group. As can be seen in Table 1, the Bielefeld group is a group of Turkish-German bilingual students who were born and raised in Germany. They were approximately 20 years of age at the time of recording (May 1994). The Bursa group is a group of Turkish-German bilingual students who were born and raised in Germany but went back to Turkey with their parents at approximately the age of thirteen. At the time of recording (November 1993) these returnees were 20 years old on average and had been back in Turkey for 7 years and 8 months. The Üsküdar group is a group of recent returnees, who are attending a so-called Anadolu lisesi ${ }^{\mathrm{x}}$ in Istanbul. They were sixteen years old on average at the time of recording (November 1994) and thus a little bit younger than the other two bilingual groups. ${ }^{x i}$ The monolingual control group (the Marmara group) are Turkish students who were born and raised in Turkey and who were around 20 years old on average at the time of recording (January/February 1995).

The informants from the four groups have a comparable educational background. The large majority of the Turkish-German bilinguals in Bielefeld, Bursa and Üsküdar attended Hauptschule in Germany, a smaller group went to the Realschule and only a few to the Gesamtschule or the Gymnasium. At the time of recording (May 1994) the informants from Bielefeld were students at the Oberstufenkolleg Bielefeld, which prepares for university studies. Without attending this college these informants would not be able to go to a university. The same is true for the Bursa group. The majority of the students in the Bursa group went to a so-called Anadolu lisesi, where some of the subjects are taught in German, some in Turkish. The Bursa informants are all students in the German department of Uludağ University in Bursa. The Marmara group is a student group from the third year of history students at Marmara University Istanbul. They have attended a so-called "normal" or public high school, generally outside Istanbul.

The large majority of the informants from the three groups of Turkish-German bilinguals come from working class families. Most of the parents are unskilled workers, smaller groups are skilled workers, traders or owners of small shops. The parents of most informants attended only primary school. The monolingual control group comes from families of which the parents were farmers, traders or small shopkeepers. Even though comparing monolingual and bilingual groups is problematic (Grosjean 1992) we believe that the social and educational background of the monolingual group and the bilingual groups is sufficiently similar to allow for a comparison.

We excluded informants about whom we did not have enough background information or whose parents had received higher education (very few in the Marmara group). 
In the Bielefeld and the Bursa groups we included only informants who were born and raised in Germany, or came to Germany within one year after birth. From the quantitative part of the study we excluded seven informants from the intermediate generation (Backus 1996) who came to Germany at later ages (or who spent a year or more in Turkey during adolescence), as there are not enough informants in this category to form a separate homogeneous group ${ }^{\mathrm{xii}}$, but we will discuss some examples of their speech in the qualitative part of the study. In order to keep the groups as homogeneous as possible we also excluded informants who came back later than 1989. As can be seen in Table 1, the pupils from Üsküdar were younger than the three student groups at recording time ${ }^{x i i i}$, and spent more time in Germany than the Bursa returnees $^{\mathrm{xiv}}$. As many returnees come back to Turkey at the age of thirteen or fourteen (Daller 1999) the Üsküdar group is thus relatively old. There are no differences between the three student groups with respect to age upon recording.

Our research assistant Kubilay Yalçın, who is a Turkish returnee from Germany, asked the informants from the Bielefeld, Bursa and Marmara groups to describe the story presented in two comic strip series (Plauen 1952) ${ }^{\mathrm{xv}}$. These strips only contain pictures ${ }^{\mathrm{xvi}}$. Yalçın transcribed the data from the first three groups as well. The data from the Marmara group were collected by Ph.D. students of the German Department of Marmara University in Istanbul, during a seminar on Bilingualism.

The data from the Üsküdar group were collected in three sessions, which took place in November 1994, May 1995 and December 1995. During the first recording session data from 23 informants were collected, but during the last session only ten of these were present. Some informants went back to Germany and some were not present during one of the three sessions. The group is therefore unfortunately fairly small.

As the individuals in each group varied with respect to the number of words they produced for the stories, and as the number of informants per group varies, we counted not only the absolute frequency of the different structures, but calculated also the relative frequency of the structures with respect to the number of utterances produced by each informant, by dividing the total number of occurrences of each variable by the total number of utterances per informant. The result was multiplied by 100 . Thus, we obtained percentages of each structure with respect to the number of utterances. Furthermore we indicate the number of speakers per group who produces a certain structure. Finally we calculated an index of syntactic complexity (SCI) on the basis of the different dependent variables. The differences in mean SCI scores were then tested with a One Way Analysis of Variance.

A few words must be said regarding our way of counting utterances. We used 
Hunt's definition of the T-Unit for our definition of utterances: "one main clause plus any subordinate clause or nonclausal structure that is attached to or embedded in it" (Hunt 1970). Co-ordinate structures beginning with ve (and), çünkü (because), ama (but) and subordinate constructions introduced by diye (so that) were considered as separate utterances. Quotations consisting of more than one constituent were considered as separate utterances, but quotations that consisted of one word or one small constituent were considered to form part of the main utterance. German utterances and metacomments were not counted.

Finally it is important to note that a few relevant utterances have been excluded from our calculations, because they did not conform to standard Turkish norms. As the number of non-targetlike structures was low in all groups, not counting these structures did not seriously affect the results. Examples are discussed in subsection 6.3.

\section{Results}

\subsection{Quantitative results}

Before we go into the results of the grammatical analysis of the data, we would like to point to the fact that there are no differences between the three student groups with respect to the number of word tokens or the number of utterances produced in the story telling task. Only the pupils produced more utterances and more word tokens than the other groups, because we analysed three picture stories per informant in this group. The calculations have been adjusted to take account of this difference. We also calculated mean length of utterance by dividing the number of word tokens by the number of utterances. An overview is given in Table 2 . Interestingly there are no significant differences between the four groups with respect to mean length of utterance. We think it is important to point to this fact, as it makes clear that the differences between the groups cannot be shown without a thorough syntactic analysis of the data.

-table 2 about here -

A detailed overview of the results can be found in Table $3 a, 3 b$ and $3 c$ 
Table $3 \mathrm{a}$ shows that verbal complements in -mAK and gerunds are used by almost all informants in all groups. Postpositional clauses occur slightly less frequently in the different groups, whereas verbal complements in -DIK and -mA, as well as the nominal adjuncts classified under -(y)AN are relatively infrequent in all groups, but especially in the Bielefeld group. The differences with respect to complements in - $\mathrm{mA}$ and $-(\mathrm{y}) \mathrm{An}$ adjuncts were found to be significant in a One Way Analysis of Variance.

Tables $3 b$ and $3 c$ give an overview of the absolute frequency and the relative frequency of the different variables. These tables show again that verbal complements in mAK, gerunds and postpositional clauses occur frequently in all groups, whereas the verbal complements in -DIK and -mA, as well as the nominal adjuncts classified under -(y)An are less frequent. The Bielefeld and Üsküdar groups obtain relatively low scores for the nominal adjuncts, but relatively high scores for the gerunds. Significant differences between the four groups are obtained for the nominal adjuncts only. In order to show the differences between the groups most clearly, we calculated an Index of Syntactic Complexity (SCI). In the calculation of this index, we started from the assumption that frequent structures (-mAK, gerunds and PPs) are easier than infrequent structures (-DIK, -(y)An and -mA). Following Hulstijn (2006) we assume that frequent morphosyntactic structures are part of the core of oral language proficiency, whereas infrequent structures are more peripheral. Thus we decided to develop an index which indicates the proportion of frequent structures (-mAK, gerunds and PPs) and infrequent structures (-DIK, -(y)An and -mA), calculated with the help of the following formula:

$\mathrm{SCI}=(\mathrm{mA}+\mathrm{An}+\mathrm{DIK}+0.5) /(\mathrm{mAK}+$ gerunds $+\mathrm{PPs}+0.5)$

We added 0.5 to the denominator and the numerator in order to avoid the problem of zero denominators. This is a standard statistical procedure. After this we calculated the logit, which is the logarithm of the index, to allow for the possibility of negative and positive scores. The index should be read as follows. Positive high scores indicate a relatively high frequency of occurrence of -mA, -(y)An and -DIK in comparison to the occurrence of -mAK, gerunds and PPs, whereas lower scores indicate a relatively low frequency of occurrence of the former in relation to the latter. A negative score means the frequency of the infrequent structures is higher than the frequency of the frequent structures. The differences between the groups on the SCI index are significant (ANOVA, $F=5.258 ; d f=3,70 ; p=.002$ ). In a post hoc analysis (Tukey HSD), the differences between the Bielefeld group on the one hand and the Bursa and 
Marmara groups on the other hand turned out to be significant.

No significant difference was found between the group index of the Üsküdar group and the other groups, probably because the Üsküdar group is rather small. When the results of the three sessions in Üsküdar are taken together, the differences between the Marmara and the Bursa groups on the one hand and the Bielefeld and the Üsküdar groups on the other hand become significant.

Figure 1 gives a graphical representation of the results of the calculation of the SCI. In the boxplots the horizontal line indicates the mean score for each group, the grey rectangles indicate the limits within which 50 percent of the scores are found, and the vertical lines delimit the area in which 95 percent of the scores are found. The Figure clearly illustrates that the two Bielefeld group and the Üsküdar group obtain lower scores on the SCI than the Bursa and the Marmara groups.

Figure 1 
It may be worthwhile pointing out that there is much intragroup variation in the Marmara group, much more than within the Bursa and Bielefeld groups. As a matter of fact, some informants from the Marmara group produce very few complex embeddings whereas others obtain high scores for complex embeddings. This may indicate that the Marmara group is not as homogeneous a group as the bilingual groups from Bursa and Bielefeld. The members of the latter two groups have a more or less similar socio-historical background, due to the fact that both groups share the migration experience, whereas there may be more variability in the background of the monolingual group. Figure 1 shows that two informants in the Bielefeld group obtained relatively high scores in comparison to the other members of their group. Similarly, there is one informant in the Bursa group whose scores are less high than that of other informants from that group. As the story telling task is intended to elicit semi-spontaneous speech, using complex embeddings is not strictly obligatory, and informants were able to use alternative structures if they preferred (see section 6.3 for more details). We believe, however, that the task is entirely appropriate for eliciting these structures, because many informants chose to use complex embeddings in narrating the stories. It seems very unlikely that the low frequency of the more complex structures among the Bielefeld and Üsküdar groups is entirely due to personal preferences rather than competence. In spite of the individual variation, Figure 1 clearly shows the differences between the groups.

\subsection{Discussion}

The results presented in the previous section confirm our prediction that the groups that have had least contact with Turkish, that is the Bielefeld and the Üsküdar groups, produce fewer complex embeddings than the Bursa and the Marmara groups. The results are most evident for the nominal adjuncts, grouped here under the label $-(\mathrm{y}) \mathrm{An}$, but there are indications that this is also true for the verbal complements in -mA (see Table 3a). The gerunds and the postpositional clauses were used frequently by all groups. As we have shown in section 4.2, most gerunds are invariable (except for allomorphic variation), and they are therefore less complex than nominal adjuncts and nominalisations. This may explain why gerunds are used frequently in all groups. The results for postpositional clauses differ from those obtained by Özsoy and Erguvanl1-Taylan (1989) for foreign language learners in that postpositional 
clauses seem to be less problematic than participles for our subjects.. As we have pointed out before, the differences may in part be due to the fact that the subjects in the study of Özsoy and Erguvanl1-Taylan had obtained formal language instruction in Turkish, during which emphasis was placed on the teaching of participles. Our results with respect to the nominal adjuncts confirm earlier findings of Boeschoten (1990) and Menz (1994), as well as those of Verhoeven (2004: 443), who concludes that the "findings show the second generation of Turkish migrants living in the Netherlands not to attain native-like levels of proficiency". The data we have found show that the same is true for Turkish migrants of the second generation in Germany: even in adulthood relative clause constructions and verbal complements are not completely acquired. It is remarkable but not unexpected that the Bielefeld and Üsküdar groups use relatively simple constructions, such as the gerunds, much more extensively whereas they avoid the more complex types of embeddings.

The data in Tables $3 b$ and $3 c$ seem to suggest that the monolinguals in the Marmara group produce more -DIK/-AcAk complements than the Bursa returnee group, even though the results are not significant. We did not expect this to be the case, as the Bursa group had been back in Turkey for almost eight years on the average at the moment of recording. The differences between the Bursa and the Marmara groups are mainly due to a few informants in the Marmara group who produce many -DIK/-AcAk complements and nominal adjuncts. As expected, there are no differences between these two groups with respect to -mA nominalisations.

\subsection{Qualitative results}

In this section we will discuss qualitative differences between the results of the four groups. The Bielefeld and Üsküdar groups produce not only fewer verbal complements, but the number of different constructions is reduced in comparison with the Bursa and Marmara groups. The Bielefeld group only produce -DIK complements but no -AcAk complements, whereas only one person in the Üsküdar group produces the -AcAk nominalisations (two constructions in total). In the Bursa and Marmara groups, on the other hand, four informants produce -AcAk complements (six constructions in total in the Bursa group and five in the Marmara group). We also find a larger variety of matrix verbs in these constructions in the Bursa and Marmara groups. Whereas the Bielefeld and Üsküdar groups only use matrix verbs assigning accusative case to their complements, we find subject complements marked with nominative, as well as object complements marked with dative, accusative and ablative case 
in the other groups. Though double embeddings are rare in all groups, there seem to be more structures containing double embeddings (exemplified in 13) in the Bursa and Marmara groups.

$$
\begin{array}{lll}
{[[\ldots \text {...sineğ-e }} & \text { vur-ma-MA -sin-1 }] & \text { öner-EN }] \quad \text { baba } \\
\text {...fly-Dat } & \text { hit-Neg-ANom-3.sgPOSS-Acc } & \text { suggest-SubjP father }
\end{array}
$$

"The father who suggested not to hit the fly." (Abdulvahap, Marmara)

In this context it is interesting to study some examples of verbal complements in - $\mathrm{mA}$ as they occur in the speech of Bielefeld informants who belong to the intermediate generation. These informants - who were not included in the quantitative part of the study because there are too few of those in our sample - produce a few more verbal complements than the students who had lived all their life in Germany, but most of these do not conform to standard Turkish norms. We have chosen two examples which relate to the part of the story in which the father tries to prevent his son from killing the fly/bee. The Bielefeld informant who produced (14) came to Germany at the age of 15 and had lived in Germany for nine years at the time of recording.

$\begin{array}{llllll}\text { Çocuk ta } & \text { sineğ-i } & \text { öl-dür-mek } & \text { ist-iyor, } & \text { ama } & \text { adam } \\ \text { child also } & \text { fly-Acc } & \text { die-Caus-Inf } & \text { want-Prog } & \text { but } & \text { man } \\ & & & \\ \text { [on-u } & \text { öl-dür-me-sin-i }] & \text { birak-mi-yor. } & \\ \text { it-Acc } & \text { die-Caus-Neg-3.sgPOSS-Acc leave-Neg-Prog } & \end{array}$

St. Turkish: onu öldürmesine izin vermiyor ("permission give”) (Bielefeld, A.F.)

"The child also wants to kill the fly, but the man doesn't give (him) permission to kill it."

The use of birakmak 'to leave, abandon', in the sense of 'allow' can possibly be explained as an interference from German lassen, which can mean 'leave me alone' in the expression lass mich, but which can also be used as an auxiliary in constructions such as Er lässt mich nicht arbeiten 'he doesn't allow me to work'.

The following example is produced by a student who was born in Germany, returned to Turkey at the age of two, and subsequently returned to Germany at the age of 15 . 
She had been living for four years in Germany at the time of recording. She uses a complement in $-\mathrm{mA}$ where a complement in $-\mathrm{mAK}$ would be required in Standard Turkish.

\begin{tabular}{|c|c|c|c|c|}
\hline Oğlan & sosis-in & üst-ün-e & vur-mak & ist-iyor \\
\hline boy & sausage-Gen & on-3.sgPOSS-Da & hit-Inf & want-Prog \\
\hline ba-s & & [on-u - & & yap-MA-sin-dan] \\
\hline & $\operatorname{sgPOSS}$ & he-Acc & & do-ANom-3.sgPO \\
\hline
\end{tabular}

alakoy-uyor

prevent-Prog

St Turkish: babasi bunu yapmaktan alakoyuyor. (Bielefeld, Yeliz).

"The son wants to hit the sausage, but his father prevents him from doing so."

With respect to the nominal adjuncts the variety of structures found in the Bursa and Marmara groups is again remarkable in comparison to the Bielefeld and Üsküdar groups. The former produce -DIK or -(y)An participles attached to passive verbs, as in (16) and they also correctly mark the grammatical relations within the participle constructions, cf. (17), whereas no correct grammatical markings of this type were observed in the Bielefeld and Üsküdar groups. Complex constructions of this type do not occur in the Bielefeld and Üsküdar groups.

$$
\begin{array}{lll}
\text { [sucuğ-un } & \text { üzer-in-de } & \text { bul-un-DUĞ-u] } \\
\text { sausage-Gen } & \text { on-3.sgPOSS-Loc } & \text { find-Pass-ObjP-3.sgPOSS } \\
\text { tabağ-1 } & \text { al-1yor } & \\
\text { plate-Acc } & \text { take-Prog } &
\end{array}
$$

"He takes the plate on which the sausage is found." (Mehtap, Bursa)

$$
\begin{aligned}
& \text { [kafa-sın-da-ki şişliğ-i gör-EN] çocuk } \\
& \text { head-3.sgPOSS-Loc-Rel.M. swelling-Acc see-SbjPart child } \\
& \text { "The child who saw the swelling on his head." (Nuray, Bursa) }
\end{aligned}
$$

The Bielefeld and Üsküdar groups use more gerunds than the Bursa and Marmara groups, but 
there is not much difference between the groups in the variety of constructions. In all four groups -Ip is the most frequent gerund. In the Üsküdar group 59\% of all gerunds are of this type, whereas in the other groups this form occurs in $40-46 \%$ of the cases. The next most frequent forms are -rken(e) and $-\operatorname{ArAk}(\mathrm{tAn})$. A third group of relatively infrequent gerunds is formed by -mAdAn, -ncA and -ndA. Complex forms in which participles are combined with zaman or sirada are found slightly more frequently in the Bursa and Marmara groups (three and four occurrences respectively). Only one occurrence of this type is found among the Bielefeld group and none of them in the Üsküdar group. There are not many differences either between the types of postpositional clauses used in both groups.

It comes as no surprise that the Bielefeld and Üsküdar groups produce more non-targetlike incomplete structures than the other groups (ten and eight non-targetlike structures in total). Two informants from the Marmara group produce a few incomplete structures, but these should probably not be considered as indications of lack of grammar knowledge. In general the number of non-targetlike structures is reduced, and not as revealing as the choice of different types of embeddings.

Nontargetlike structures occur, for example, in the use of possessives and genitives, as in (18), where the informant uses two possessives on the word $o g y l$ 'son', or in case assignment, as in (19) where the subject uses dative case instead of locative on the postposition üst 'on' which is commonly used in Standard Turkish.

$\begin{array}{lccc}\text { Baba-s1 } & \text { oğl-u-sun-a } & \text { kız-1yor } & \text { ve } \\ \text { Father-3.sg } & \text { son-3.sgPOSS-3.sgPOSS-Acc be+angry-Prog } & \text { and } \\ \text { oğl-u-su } & \text { başl-1yor } & \text { ağla-ma-ya } & \\ \text { son-3.sgPOSS-3.sgPOSS } & \text { start-Prog } & \text { cry-ANom-Dat } & \end{array}$

"The father is angry at his son and the son starts crying." (Bielefeld, Serkan)

(19)

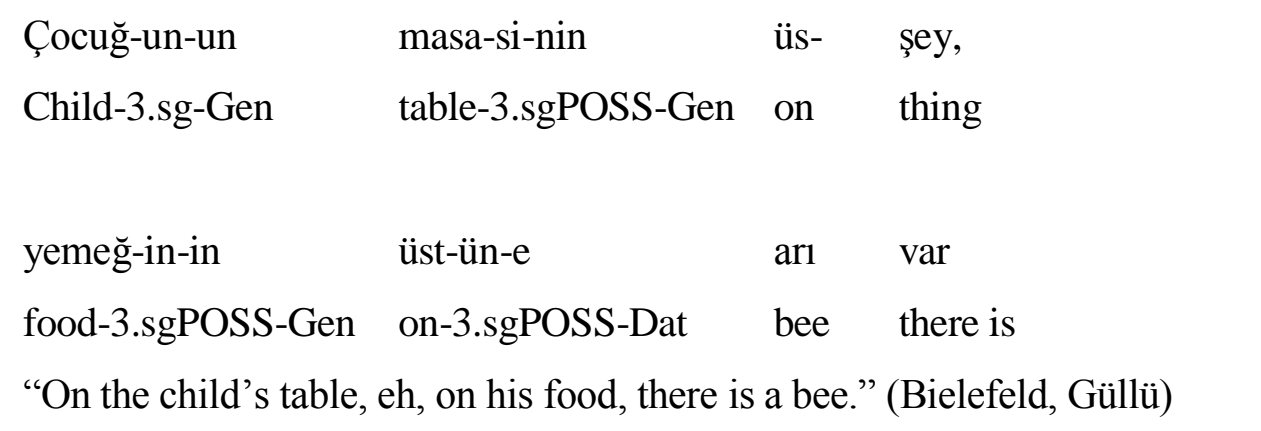

In (20) the informant omits the dative case on öldür-me 'kill-ANom', which is required in 
Standard Turkish if the matrix verb is ŭgraş- (to hit).

$$
\begin{array}{lllllll}
\text { Bir } & \text { eh } & \text { gazete } & \text { gibi } & \text { bir } & \text { şey } & \text { getir-iyor } \\
\text { One } & \text { eh } & \text { newspaper } & \text { like } & \text { a } & \text { thing } & \text { bring-Prog }
\end{array}
$$

[öl-dür-ME] uğraş-1yor.

die-Caus-ANom struggle-Prog

"He brings something like a newspaper and struggles to kill (it)." (Bielefeld, Nurhan). St. Turkish öldürmeğe uğraşıyor

\subsection{Alternative structures}

A comparison of a particular event in the story - the moment at which the father tells the son not to kill the bee - reveals the fact that students from Bursa and Marmara on the one hand and from Bielefeld and Üsküdar on the other hand, use different strategies to explain this event. In order to facilitate the comparison of the structures, the relevant parts in the utterance are indicated in bold-type. The Bursa students frequently use nominalisations in $-\mathrm{mA}$ in this part of the story (cf. 21), whereas almost all students from Bielefeld avoid these at this point in the story. Instead, they use direct speech (22 and 23) or a construction with $k i$ 'that' (24) or avoid telling this part of the story. Only one student from the Bielefeld group uses a nominalisation (25).

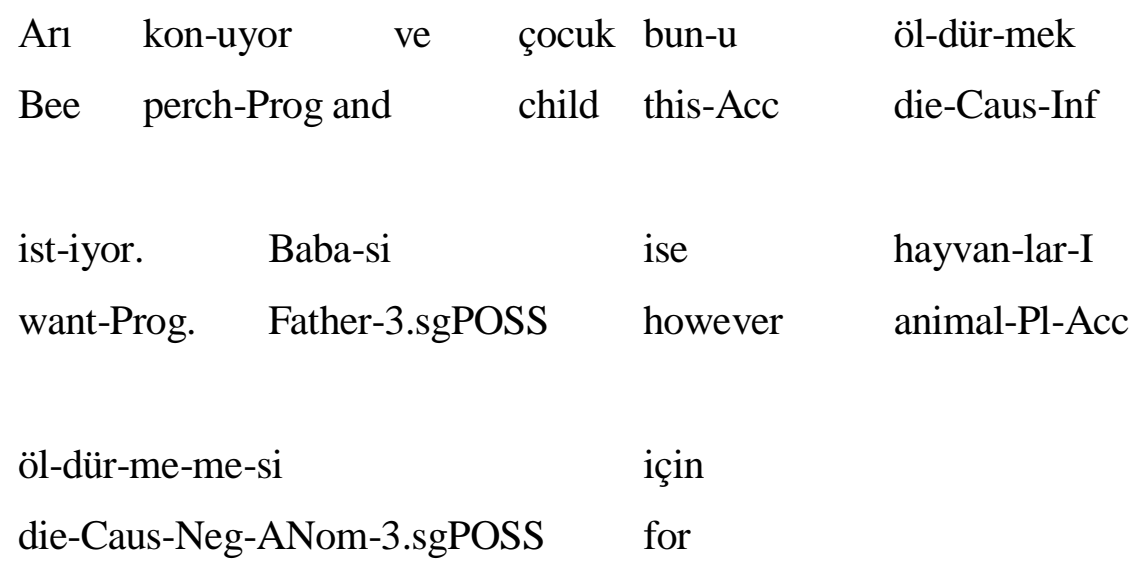

\section{öl-dür-me-me-sin-i}


die-Caus-Neg-ANom-3.sgPOSS-Acc

söyl-üyor

tell-Prog

"The bee perches (on his food) and the child wants to kill it. His father however tells him not to kill it." (Bursa, Orhan)

(22)

Çocuk sineğ-i vur-mak ist-iyor. Baba-si

Child fly-Acc hit-Inf want-Prog Father-3.sgPOSS

di-yor: "hayir, yap-ma!"

say-Prog no, do-Neg

"The child wants to kill the fly. His father says: No, don't!" (Bielefeld, Fevzi)

(23)

$\begin{array}{lllll}\text { Bez-le } & \text { ar1-y1 } & \text { kov-mak } & \text { ist-iyor. } & \text { O } \\ \text { Cloth-Inst } & \text { bee-Acc } & \text { chase-Inf } & \text { want-Prog } & \text { that }\end{array}$

an-da baba-s1 di-yor ki, eh

moment-Loc father-3.sgPOSS say-Prog that eh

$\begin{array}{lllll}\text { el-ler-in-i } & \text { "hayır" } & \text { bir } & \text { vaziyet-te } & \text { göster-iyor } \\ \text { hand-Pl-3.sgPOSS-Acc } & \text { no } & \text { one } & \text { posture-Loc } & \text { show-Prog }\end{array}$

"He wants to chase the bee with a cloth. At that moment, his father says that, eh, he shows his hands in a "no" kind of way." (Bielefeld, Cüneyt)

(24)

Çocuk döv-mek ist-iyor, baba-s1 diyor

Child hit-Inf want-Prog father-3.sgPOSS say-Prog

ki döv-mey-ecek-sin, diye... (Bielefeld, Selma)

that hit-Neg-Fut-2sg that

"The child wants to hit (it), but his father says that he shouldn't kill (it)."

$\begin{array}{llllll}\text { Çocuk da } & \text { bun-u } & \text { bir } & \text { bez-le } & \text { kovala-mak } & \text { ist-iyor. } \\ \text { Child also } & \text { that-Acc } & \text { a } & \text { cloth-Inst } & \text { chase-Inf } & \text { want- }\end{array}$




\begin{tabular}{|c|c|c|}
\hline Baba-s1 & yap-ma-ma-sın-ı & söyl-üyor \\
\hline Father-3.sgPOSS & do-Neg-ANom-3.sgPOSS-Acc & tell-Prog \\
\hline
\end{tabular}

While all versions of the story are grammatical and acceptable ways of relating this event, the avoidance of complex embeddings among the Bielefeld students is salient, and is probably an indication that most Bielefeld students do not have an active command of these structures. It is possible that the Bielefeld students have a passive command of the complex embeddings they do not actively produce, but we cannot assess this in a productive task such as the one we used. It would be very interesting to investigate the students' processing of sentences containing nominalisations, but this is beyond the scope of the present study.

\section{General conclusion}

In this study we looked in detail at complex embeddings in the speech of three different groups of Turkish-German bilinguals and one monolingual control group. We found significant differences between the Bielefeld and the Üsküdar groups on the one hand, and the bilingual returnee group from Bursa and a monolingual control group on the other hand. This result was obtained with the help of a Syntactic Complexity Index (SCI), which indicates the ratio of infrequent structures (-DIK, -(y)An and -mA) over frequent structures (-mAK, gerunds and PPs). As expected, the main result of this comparison was that the Bielefeld and Üsküdar groups, who had had least contact with Turkish as spoken in Turkey, obtain significantly lower scores on our index. Another main result of our study is that the Bielefeld and Üsküdar groups make extensive use of the simpler types of embeddings, that is the gerunds, and, as far as the Bielefeld group is concerned, the -mAK nominalisations. The extensive use of these constructions is revealed in both the absolute and the relative frequency 
of the structures. This result is perhaps the most interesting finding, as it is less predictable than the mere fact that the Bielefeld and Üsküdar groups obtain lower scores on our index of syntactic complexity. It is important to note in this context that bilinguals in Germany often successfully use other strategies, such as direct speech or paraphrases, to describe the events in the narrative.

The data discussed in this paper provide a clear illustration of Grosjean's (1997) complementarity principle: informants who have had most contact with Turkish as spoken in Turkey choose from a variety of constructions, whereas the group in Germany and those who have returned recently have a more limited stylistic repertoire. It is only through a quantification based on an in-depth analysis of the different types of embeddings that this result could be obtained. As we have seen above, the differences between the groups cannot be demonstrated with the help of simple quantitative measures, such as mean length of utterance, mean number of utterances or mean number of word tokens.

The results are important for educational policies in Western Europe, as the lack of development of the L1 of migrants is considered to be a crucial (though not the only) factor in the relatively poor performance of many immigrants in Western Europe and Germany in particular (see section 1). Schools could play an important role in furthering L1 knowledge among their Turkish students. In this respect it is important to note that in our study informants in Bielefeld of the intermediate generation, who had often spent a few years in the Turkish educational system, seemed to have a better grasp of complex embeddings than students of the second generation, who have never been to a Turkish-medium school. These results confirm Yağmur's (1997) conclusion that receiving education through the medium of L1 plays a role in the maintenance of $\mathrm{L} 1$.

The results can also shed some light on the development of European varieties of Turkish. The data from our Turkish-German bilinguals provide evidence for Slobin's (1977: 194) general principle of language contact, which posits that "forms which are late to be acquired by children are presumably also relatively difficult for adults to process, and should be especially vulnerable to change." Informants of the second generation fail to acquire a number of aspects of Turkish grammar, and replace these with more analytical means of expression. This could lead to what Verhoeven (2004: 443) calls "a substantial erosion of the grammatical system of Turkish" as spoken in Germany, especially if the Turkish of the second generation becomes the main source of input for the 
following generations.

The results indicate that Turkish students who have lived all their life in Germany are indeed 'incomplete learners' (Polinsky 2004) in that most of them do not completely acquire the range of complex embeddings that is found among Turkish students (monolinguals and bilinguals) who have grown up in a Turkish environment, and have received at least part of their education through the medium of Turkish. It is interesting that informants of the intermediate generation, who have spent a few years in Turkey in childhood or adolescence, appear to have acquired some of the more complex constructions, but do not use them in the same way as monolingual and bilingual speakers who live in Turkey. The students of the intermediate generation can therefore be said to have an "intermediate competence" in this area, in between the students who were born in Germany and those who returned to, or have always lived in Turkey. The returnees do finally acquire complex embeddings, but most of them only do so after their return to Turkey. We can conclude this from the fact that these structures are still relatively infrequent in the speech of returnees who were recorded within a few months after arrival in Turkey, whereas returnees who had lived in Turkey for eight years at the moment of data collection are indistinguishable from monolingual Turkish students in this respect.

Another point worth investigating in the future is the bilingual students' ability to understand and process sentences containing complex embeddings, as this could give additional information about the informants' syntactic proficiency. This issue could not be investigated on the basis of the production task. Furthermore, it would be interesting to find out how much time returnees need to acquire active command of complex embeddings. Future research could be directed towards an investigation of these issues. 


\section{References}

Aissati, Abder El and Anneli Schaufeli (1999) Language maintenance and loss: evidence from language perception and production. In: Guus Extra and Ludo Verhoeven (eds.) Bilingualism and Migration. Berlin: Mouton de Gruyter, pp. 363-377.

Akinci, M.-A. (2001) LINCOM Studies in language acquisition. Vol. 3. Développement des compétences narratives des enfants bilingues turc-français en France, âgés de 5 à 10 ans. Munich: Lincom.

Aksu-Koç, Ayhan A. (1994) Development of linguistic forms: Turkish. In: Ruth R. Berman and Dan Isaac Slobin (eds.) Relating events in narrative: a crosslinguistic developmental study. Hillsdale etc.: Lawrence Erlbaum Associates, pp. 329-385.

Auer, Peter \& Inci Dirim (2000) On the use of Turkish routines by adolescents of nonTurkish descent in Hamburg. In A.Holmen and J.N.Jørgensen (eds.) Copenhagen Studies in Bilingualism: the Køge series. Volume 7: Det er Conversation 801, değil mi? Perspectives on the Bilingualism of Turkish speaking Children and Adolescents in North-Western Europe, p.. 159-94. Copenhagen: The Danish University of Education.

Backus, Ad (1996) Two in one. Bilingual speech of Turkish immigrants in the Netherlands. Tilburg University. Studies in Multilingualism, Volume 1.

Backus, Ad (2004) Turkish as an immigrant language in Europe. In Tej K. Bhatia and William C. Ritchie (eds.) The Handbook of Bilingualism. Oxford: Blackwell, pp. 689-724.

Bayraktaroğlu, A. Non-standard uses in the mother tongue by the Turkish diaspora adolescents in England. In: Bayraktaroğlu (ed.) TASG News. Newsletter of the Turkish Area Studies Group, 49. (special edition: Turkish language in diaspora), 28-39.

Birdsong, D. (2004). Second language acquisition and ultimate attainment. In A. Davies \& C. Elder (Eds.), The Handbook of Applied Lingustics (pp. 82-105). Oxford, UK: Blackwell 
Boeschoten, H.E. (1990), Acquisition of Turkish by Immigrant Children, a multiple case study of Turkish children in the Netherlands aged 4 to 6, dissertation, Katholieke Universiteit Brabant, Tilburg, The Netherlands

Boeschoten (1992), "The influence of a second language on the acquisition of a first language: the case of Turkish in Germany." Presentation at the KNAW symposium "Early bilingualism". Amsterdam

Boeschoten, Hendrik and Lars Johanson (2006) Turkic Languages in Contact. Wiesbaden: Harrassowitz Verlag.

Daller, Helmut (1996) Der C-Test als Meßinstrument alltagssprachlicher und akademischer Sprachfähigkeiten türkischer Remigranten. In Grotjahn (1996) (ed.) Der C-Test.

Theoretische Grundlagen und praktische Anwendungen. Band 3. Bochum: Brockmeyer, 343-366.

Daller, Helmut (1999) Migration and Mehrsprachigkeit. Der Sprachstand türkischer Rückkehrer aus Deutschland. Frankfurt am Main: Peter Lang.

Daller, Helmut, Roeland van Hout and Jeanine Treffers-Daller (2003) 'Measuring lexical aspects of oral language proficiency among bilinguals: an analysis of different measurements', Applied Linguistics 24/2: 197-222

Fritsche, Michael (1982) Mehrsprachigkeit in Gastarbeiterfamilien. "Deutsch" auf der Basis der türkischen Syntax. In: Bausch, K.G. (ed.) Mehrsprachigkeit in der Stadtregion. Sprache der Gegenwart 56. Jahrbuch 1981 des Instituts für Deutsche Sprache. Düsseldorf: Schwann.

Grosjean, François (1992) "Another view of bilingualism". In Harris, Richard Jackson (ed.) Cognitive Processing in Bilinguals, Amsterdam: Elsevier Science Publishers, 51-62.

Grosjean, François (1997) "The bilingual individual. Interpreting: International Journal of Research and Practice in Interpreting, (1/2), 163-187. 
Grosjean, F. (1998, 2004). Studying bilinguals: Methodological and conceptual issues. Bilingualism: Language and Cognition, 1 (2), 131-149. Also in T. K. Bhatia \& W. C. Ritchie (Eds.). The Handbook of Bilingualism (pp. 32-63). Oxford, England: Blackwell Publishing.

Fritsche, M. (1982), "Mehrsprachigkeit in Gastarbeiterfamilien. "Deutsch" auf der Basis der türkischen Syntax", In: Bausch, K.H. (ed.) Mehrsprachigkeit in der Stadtregion, Sprache der Gegenwart 56, Jahrbuch 1981 des Instituts für deutsche Sprache, Düsseldorf: Schwann.

George, N and Jaklin Kornfilt (1981) Finiteness and boundedness in Turkish. In: F. Henry (ed.) Binding and Filtering. Cambridge: MIT Press, pp. 105-127.

Hulstijn, Jan (2006) Defining and measuring the construct of second/language proficiency. Plenary address, held at the joint conference of the American Association for Applied Linguistics (AAAL) and the Association canadienne de linguistique appliqée/Canadian Association of Applied Linguistics ACLA/CAAL, Montreal, June 17/20, 2006

Hunt, K.W. (1970), Syntactic maturity in school children and adults, Monographs of the society for Research in Child Development, Serial no. 134, vol. 35, no. 1.

Issa, Tözün (2005) Talking Turkey. The language, culture and identity of Turkish-speaking children in Britain. Stoke-on-Trent: Trentham books.

Johanson, Lars (1999) Frame-changing code-copying in immigrant varieties. In Guus Extra and Ludo Verhoeven (eds.) Bilingualism and Migration. Berlin: Mouton de Gruyter, 247260.

Karasu, Ibrahim (1995) Bilinguale Wortschatzentwicklung türkischer Migrantenkinder vom Vor- bis ins Grundschulalter in der Bundesrepublik Deutschland. Berlin:Lang.

Kornfilt, Jaklin (1997) Turkish. London and New York: Routledge. 
Mayer, M. (1969) Frog, where are you? New York: Dial Press.

Menz, Astrid (1994) Studien zum Türkisch der zweiten deutschland-türkischen Generation, Magisterarbeit, Fachbereich 15, Philologie III der Johannes Gutenberg-Universität Mainz.

Montrul, Silvina (2002). Incomplete acquisition and attrition of Spanish tense/aspect distinctions in adult bilinguals. Bilingualism, Language and Cognition 5 (1), 39-68.

Özcan, Veysel (2004) Germany: Immigration in Transition. URL:

http://www.migrationinformation.org/Profiles/display.cfm?id=235 [accessed 22 October 2006]

Özsoy, A. S. (1999) Türkçe. İstanbul: Boğaziçi University Press ( $2^{\text {nd }}$ Edition).

Özsoy, Sumru and Eser Erguvanl1-Taylan (1989), "Belirtilik ve kavramı ve yabanc1 dil olarak türkçe. In: F. Özden, Ekmekçi and Vural Ülkü (eds.) Dil Bilimi Uygulamaları, 187-203.

Pfaff, C. W. (1991), "Turkish in contact with German: Language maintenance and loss among immigrant children in Berlin (West)", International Journal of the Sociology of Language 90, 97-129

Pfaff, C.W. (1994) Early bilingual development of Turkish children in Berlin. In Guus Extra and Ludo Verhoeven (eds) The cross-linguistic study of bilingual development. Amsterdam: Koninklijke Academie van Wetenschappen, 75-97.

Plauen, E.O. (= Erich Ohser). (1986). Vater und Sohn (Band 2). Ravensburger Taschenbuchverlag.

Polinsky, Maria (2004). Word class distinctions in an incomplete grammar. In Dorit Ravid and Hava Bat-Zeev Shyldkrot, eds. Perspectives on language and language development. Dordrecht: Kluwer. 
Preibusch, Wolfgang (1992) Die deutsch-türkische Sprachenbalancen bei türkischen Berliner Grundschülern. Eine clusteranalytische Untersuchung. Frankfurt: Lang.

Rehbein J. (1987), "Sprachloyalität in der Bundesrepublik? Ausländische Kinder zwischen Sprachverlust and zweisprachiger Erziehung", Universität Hamburg: Arbeiten zur Mehrsprachigkeit 26.

Sar1, Maksut (1995) Der Einfluß der Zweitsprache (Deutsch) auf die Sprachentwicklung türkischer Gastarbeiterkinder in der Bundesrepublik Deutschland. Frankfurt: Lang

Schaufeli, A. (1991), Turkish in an immigrant setting. A comparative study of the first language of monolingual and bilingual Turkish children, Dissertation, Universität von Amsterdam

Slobin, Dan (1977) Language Change in Childhood and in History. In: John Macnamara (ed.) Language Learning and Thought (pp. 185-214). London etc.: Academic Press.

Slobin, Dan (1986) The acquisition and use of relative clauses in Turkic and IndoEuropean languages. In D.I. Slobin and K. Zimmer (eds.) Studies in Turkish Linguistics. Amsterdam/Philadelphia: Benjamins, 273-294.

Stanat, Petra. (2003). Schulleistungen von Jugendlichen mit Migrationshintergrund: Differenzierung deskriptiver Befunde aus PISA und PISA-E [Learning outcomes of students from immigrant families: A differentiated look at descriptive findings from PISA and PISA-E]. In J. Baumert, C. Artelt, E. Klieme, M. Neubrand, M. Prenzel, U. Schiefele, W. Schneider, K.-J. Tillmann, \& M. Weiß (Eds.), PISA-2000 - Ein differenzierter Blick auf die Länder der Bundesrepublik Deutschland (pp. 243-260). Opladen: Leske + Budrich.

Sarı, Maksut (1993) Der Einfluß der Zweitsprache Deutsch auf die Sprachentwicklung türkischer Gastarbeiterkinder in der Bundesrepublik Deutschland, Peter Lang: Frankfurt am Main 
Treffers-Daller, Jeanine and A. Sumru Özsoy (1995) "Mündliche Sprachfähigkeiten von türkisch-deutschen Bilingualen in Deutschland and in der Türkei: eine syntaktische Analyse von türkischen Bildbeschreibungen, in Treffers-Daller, Jeanine and Helmut Daller (eds.) Zwischen den Sprachen. Sprachgebrauch, Sprachmischung and Sprachfähigkeiten türkischer Rückkehrer aus Deutschland. Band 2. The Language Center, Boğaziçi University, 95-122.

Treffers-Daller, Jeanine and Roeland van Hout (1999) De meting van woordenschatrijkdom in het Turks van Turks-Duits tweetaligen. In: Huls, Erica and Bert Weltens (eds.), Artikelen van de derde sociolinguïstische conferentie, Eburon: Delft, 429440.

Türker, Emel (2000) Turkish-Norwegian codeswitching. Evidence from intermediate and second generation Turkish immigrants in Norway. University of Oslo.

Underhill, R. (1972) Turkish Participles. Linguistic Inquiry 3 (1): 87-99.

Valdés, Guadalupe. 2000. Spanish for Native Speakers. Vol. 1. New York, NY: Harcourt College Publishers.

Verhoeven, Ludo (1989) Acquisition of clause-linking in Turkish. In: H.Bennis and A. van Kemenade (eds.). Linguistics in the Netherlands 1989. Dordrecht: Foris, p..153-162.

Verhoeven, Ludo (1991) Acquisition of Turkish in a mono- and bilingual context. In: H. Boeschoten and L. Verhoeven (eds.) Turkish Linguistics today. Leiden: Brill, pp. 113-149.

Verhoeven, Ludo (2004) Bilingualism and narrative construction. In: Sven Strömqvist and Ludo Verhoeven (eds.) Relating events in narrative, volume 2: typological and contextual perspectives. London: Lawrence Erlbaum, pp. 435-454.

Verhoeven, L.Th. and H. Boeschoten (1986), "First language acquisition in a second language submersion environment, in: Applied Linguistics, vol. 7, 241-256

Yağmur, Kutlay, Kees de Bot and Hubert Korzilius (1999) Language Attrition, Language 
shift and ethnolinguistic vitality of Turkish in Australia. Journal of Multilingual and Multicultural Development, volume 20 91), 51-69. 
i. The data we discuss here were collected in the framework of a research project which focused on vocabulary richness and syntactic proficiency of different groups of Turkish-German bilinguals.

We are particularly grateful to the Research Fund of Boğaziçi University (grant number 95006) and the Language Contact Fund of the University the Netherlands Institute for Advanced Study in the Humanities and Social Sciences (NIAS). We are very grateful to Kubilay Yalçın for collecting and transcribing the data from the Bielefeld, Bursa and Üsküdar groups. Aybars Akdaş, Ragıp Başbağı, Erol Hacısalihoğlu and Mustafa Kınış have been very helpful in collecting and transcribing the data from the Marmara group. An earlier version of this article appeared in Boeschoten and Johanson (2006).

ii As one reviewer points out, using the notion "syntactic proficiency" can be problematic in relation to immigrant varieties of Turkish, as the norms of Turkish as spoken in Germany are not as well-defined as those of Standard Turkish. In this paper, we aim to contribute to providing more insight into these norms by analysing the structural properties of Turkish as spoken in Germany.

iii Daller (1999) shows that the returnees used to speak Turkish more with their parents than with their siblings and friends, before arrival in Turkey (reported language use). After their return, German is used significantly less with all groups, but there is particularly dramatic reduction in the use of German with peers. The reduction in use of German is more strongly observed among the student population than among the secondary school pupils. This in turn reflects the fact that the students had returned to Turkey many years before the secondary school pupils. According to Daller (1999), this can be an indication that language use patterns change relatively slowly over time.

${ }^{\text {iv }}$ Website of the German federal ministry of the Interior. http://www.zuwanderung.de/english/1_statistik.html [accessed 22 October 2005]. Source: Migration Policy Institute.

${ }^{\mathrm{v}}$ The PISA study was initiated by the Organisation for Economic Cooperation and Development (OECD) as part of its INES programme, which provides the OECD member countries with internationally comparable data about their educational systems. The data were collected between 2000-2003. They compare student achievement of 15-yearolds from 32 different countries. An English summary of the study can be found on the following URL: http://www.mpib-berlin.mpg.de/pisa/PISA-2000_Overview.pdf

${ }^{\text {vi. }}$ Sevgi (born 1971, returned to Turkey in 1985, recorded in Bursa in 1993): "Nach der Rückkehr hat es ungefähr ein Jahr gedauert bis ich ordentlich Türkisch konnte." [After return to Turkey it took me about a year to speak Turkish properly].

vii The following Abbreviations are used in the glosses, which are based on the examples given in Kornfilt (1997):

Abl - Ablative; Acc - Accusative; ANom -Action nominal; Aor - Aorist; Caus Causative; Dat - Dative; FNom - Factive nominal; FNom.Fut - Factive nominal future; Fut - Future; Fut.ObjP - Future object Participle; Gen - Genitive; Ger - Gerund; Inf Infinitive; Inst - Instrumental; Int - interjection; Loc - Locative; Neg - Negation; Pass - 
Passive; Prog - Progressive; Rel .M. - Relative Marker; RepPast - Reported Past; ObjP Object Participle; Pl - Plural; PragmPart - Pragmatic particle; SbjP - Subject Participle; $1 \mathrm{sg}$ - first person singular; $2 \mathrm{sg}$ - second person singular; $3 \mathrm{sg}$ - third person singular; 3 sg.Poss -third person singular possessive; $1 \mathrm{pl}$ - third person plural; $2 \mathrm{pl}$ - second person plural; $3 \mathrm{pl}$ - third person plural.

Most suffixes are subject to allomorphic variation. Thus, for example, the suffix $-\mathrm{mA}$ can be realised as -me or -ma depending on the vowel of the root. Capital letters are used to represent the sounds that are variable.

viii The suffixes take different forms due to different assimilation processes, which we cannot discuss here.

${ }^{\text {ix }}$ We follow the transcription conventions of Kornfilt (1997: 281) who considers the first $-\mathrm{n}$ in onun to be part of the root rather than part of the genitive suffix of the pronoun $o$ 'he'.

${ }^{\mathrm{x}}$ The Anadolu lisesi is a state school, in which part of the curriculum is taught in a foreign language. Some of the Anadolu lisesi's were created specifically for returnee students.

${ }^{x i}$ We recorded this group three times, between November 1994 and December 1995. The number of informants in this group is relatively small, as we included only those students who were present at three data collection sessions.

xii The students in this group spent a varying number of years in Turkey prior to emigration to Germany: some spent a few years in primary school, others also a few years in secondary school. The group can therefore not be considered to form a homogeneous group.

xiii. The pupil group from Üsküdar differences significantly in age upon recording from the three other groups. The student groups do not differ from each other with respect to this variable. (One Way Anova. F ratio 22.1; $<$.001; Tukey HSD).

xiv. T-test, t-value $=-6.96, \mathrm{df}=26, \mathrm{p}<.001)$.

xv. The Bursa group had only been presented with two picture series, whereas the other groups were asked to describe three picture series. For the sake of comparability we used only the two first stories from all informants. In the Bielefeld group, we added data from the third story telling series for two informants who produced too few words during the first two stories.

${ }^{x v i}$ The plot lines of the stories are as follows: In one of the stories, the father and the son play football in the street. The ball then rolls into a drain, and the father goes down the drain to fetch it. When he returns, the boy kicks him on his head, as he thinks the father's head is the ball. In the other story, the father and the son are eating a sausage at the dinner table. A bee or a wasp flies into the room and perches on the child's sausage. As the child prepares to kill it, the father prevents him from doing so. Instead he takes the plate with the sausage and the insect to the window, in the intention to let it fly away. The insect flies away but comes back, perches on the father's head and stings him. The father then kills the insect.

In the third story (told by the Üsküdar pupils only), the father helps his son with his homework, probably by doing the work himself, but the teacher discovers that the boy has not done the work himself. He takes the boy home and gives the father a spanking. 